\title{
Developmental pathway of somatic embryogenesis from leaf tissues of macaw palm (Acrocomia aculeata) revealed by histological events
}

\author{
Filipe Sathler Meira ${ }^{\mathrm{a}}$, Zanderluce Gomes Luis ${ }^{\mathrm{b}}$, Inaê Mariê de Araújo Silva-Cardoso ${ }^{\mathrm{a}}$, \\ Jonny Everson Scherwinski-Pereira ${ }^{\mathrm{C}, *}$ \\ ${ }^{a}$ Universidade de Brasília, Campus Universitário Darcy Ribeiro, Brasília, DF, Brazil \\ ${ }^{\mathrm{b}}$ Universidade Federal do Sul e Sudeste do Pará (Unifesspa), Marabá, PA, Brazil \\ ${ }^{\mathrm{c}}$ Embrapa Recursos Genéticos e Biotecnologia, Av. W5 Norte (final), PqEB, 70770-917, Brasília, DF, Brazil
}

\section{A R T I C L E I N F O}

Edited by Alessio Papini

Keywords:

Arecaceae

Morphogenesis

Somatic embryo

Somatic tissues

Ontogenesis

Woody plants

\begin{abstract}
A B S T R A C T
This paper, in an unprecedented way, describes the ontogenesis of calli and somatic embryos of macaw palm (Acrocomia aculeata) from young leaf tissues of adult plants, aiming to elucidate the events underlying the process and consequent optimization of the technique. Leaves were inoculated in a callus induction medium, composed of Y3 salts, $2.5 \mathrm{~g} \mathrm{~L}^{-1}$ activated charcoal and $450 \mu \mathrm{M}$ Picloram. For multiplication of the calli, they were separated from the explants and inoculated in a medium with the same composition as the previous phase. Histological analyses were performed on samples of immature leaves with and without calli at $0,3,15,30,60$, 90 and 120 days in an induction medium, and on samples of the different types of calli and somatic embryos obtained during multiplication and differentiation. For this, the samples were fixed in FAA, dehydrated in an alcohol series and infiltrated in resin. Anatomical sections obtained on a microtome were stained with Toluidine Blue for structural characterization. At 60 days, analyses revealed the formation of callogenic masses in the vicinity of smaller vascular bundles. This multiplication approach allowed for the proliferation of the primary cell mass that evolved into new lineages of calli, especially the embryogenic yellowish nodular lineage, which originated somatic embryos. Additional histochemical analyses showed starch accumulation only in the adjacencies of areas undergoing intense cell division. The morpho-anatomic characterization allows the rapid identification of potential calli for the formation of somatic embryos from leaf tissues in macaw palm and promotes future investigations of the participation of vascular tissues in the events that precede somatic embryogenesis.
\end{abstract}

\section{Introduction}

The macaw palm [Acrocomia aculeata (Jacq.) Lodd. ex Mart.] is a monocotyledon species, a member of the Arecaceae family. This palm tree is native to tropical regions of the Americas, occurring naturally from southern Mexico and the Caribbean to Paraguay and northern Argentina (Ciconini et al., 2013). In Brazil, it is considered one of the most dispersed species of palm tree, with natural populations occurring practically throughout the nation (Scariot et al., 1991; Henderson et al., 1995; Lorenzi et al., 2010; Amaral et al., 2011).

Macaw palm, also known as bocaiúva palm, is traditionally used for various economic purposes, and almost all parts of the plant can be harvested, including leaves, stipes, fruits and seeds (Lorenzi and Negrelle, 2006; Lorenzi, 2006; Ciconini et al., 2013). Despite the different uses, the main source of income related to the commercialization of the species is the fruit, with high oil content that can be compared to the African oil palm, the world's foremost source of vegetable oil (Zelt, 2018). In fact, the use of macaw palm fruits has been the main focus of the products generated by this species, since the oil extracted from them can be used in the production of biodiesel (Teixeira, 2005; Amaral et al., 2011; Matsimbe, 2012). The oil productivity of this palm can vary between 1500 to $6,200 \mathrm{~kg}$ per hectare (Lleras and Coradin, 1985; Wandeck and Justo, 1988; Teixeira, 2005; Dias, 2011; Zelt, 2018). Due to these high yields, macaw palm is projected as a possibility to stimulate the biodiesel industry in Brazil, as well as diversification of the Brazilian and Latin American energy base (César et al., 2015). Moreover, there is the potential use of oil in the fields of medicine and nutrition, highlighting the photoprotection characteristic (given the high content of fatty acids, polyphenols and $\beta$-carotene) (Dario et al., 2018), as well as food (as a source of carotenoids and tocochromanols) (Schex

\footnotetext{
* Corresponding author.

E-mail address: jonny.pereira@embrapa.br (J. Everson Scherwinski-Pereira).
} 
et al., 2018), in addition to its antidiabetic and antioxidant properties (Silva et al., 2018).

Due to these potential uses, the macaw palm is undergoing a strong domestication process in Brazil (Montoya et al., 2016). Granja et al. (2018) warn of the need to carry out good agricultural practices and legitimized cultivars, which guarantee the uniformity of plants and, consequently, the success of the crop. In this context, in vitro cultivation techniques, in particular somatic embryogenesis, can be considered as an important technique used to ensure the efficient vegetative propagation of genotypes of interest, for the development of cultivars and the consequent leverage of macaw palm crops, since the species does not form tillers, and it is practically impossible to use conventional techniques for the asexual reproduction of this plant.

In fact, somatic embryogenesis has been the focus of several researchers, and protocols for somatic embryogenesis have been described for different palm species, such as Phoenix dactylifera (Fki et al., 2003; Sané et al., 2006; Othmani et al., 2009), Elaeis guineensis (Ahée et al., 1981; Teixeira et al., 1993; Scherwinski-Pereira et al., 2010; Silva et al., 2012; Balzon et al., 2013), A. aculeata (Moura et al., 2009; Luis and Scherwinski-Pereira, 2014), Euterpe oleracea (Scherwinski-Pereira et al., 2012) and Bactris gasipaes (Steinmacher et al., 2007; Heringer et al., 2014). In macaw palm, despite the importance of somatic embryogenesis for enabling clonal propagation of superior genotypes, the technique is non-existent in the literature regarding the practical results, especially when it is aimed to regenerate plants from already differentiated somatic tissues, necessitating more detailed studies of the several different aspects involved in the process.

The study of somatic embryogenesis through histological observations has proved to be increasingly useful, encompassing the use of various techniques that allow the events that occur when plant species are cultivated in vitro to be detailed. In this way, for example, it is possible to know and monitor the cell and tissue development of plant material during the different stages of the process of somatic embryogenesis, as well as to identify the more responsive and/or embryogenic tissue and/or cell markers earlier in the process (Gomes et al., 2017). Moreover, histological analyses make it possible to elucidate aspects related to the somatic-embryogenic cell transition, which are rather unclear, especially in palm trees.

Anatomical analyses of the macaw palm are non-existent when it comes to the ontogenesis of the formation of calli and somatic embryos derived from the leaves of adult plants. On the other hand, anatomical analyses related to somatic embryogenesis in macaw palm from zygotic embryos have been reported by some researchers (Moura et al., 2009; Luis and Scherwinski-Pereira, 2014). In this regard, the aim of this study was to elucidate for the first time the ontogenesis during somatic embryogenesis of macaw palm (Acrocomia aculeata) from leaf tissues of adult plants, in order to better understand the events involved in the process and to elucidate points of the process heretofore unknown for this species.

\section{Material \& methods}

\subsection{Plant material}

To obtain calli, young and non-expanded leaves (palm hearts) of Acrocomia aculeata were obtained from an adult plant selected from a natural population located in the rural region near the Fercal Housing Sector in Sobradinho, DF (Coordinates: $1^{\circ} 35^{\prime} 37.6^{\prime \prime}$, 47 ${ }^{\circ} 54^{\prime} 36.1^{\prime \prime} \mathrm{W}$ ).

After being collected in the field, the plant material was taken to the laboratory, where the outermost leaves were removed and the size of the palm heart reduced to approximately $30 \mathrm{~cm}$ in length (in the direction from the meristematic base to the leaf apex of the central cylinder).

The palm heart consisting exclusively of achlorophyllous leaves was disinfested under laminar flow chamber conditions, by immersion in $70 \%$ alcohol for three minutes, sodium hypochlorite $(2.5 \%$ active chlorine) for $20 \mathrm{~min}$, followed by a triple wash in distilled water and autoclaved. After disinfestation, the leaves were excised in $1.0 \mathrm{~cm}^{2}$ explants, which were standardized maintaining three leaf blades per explant.

After asepsis of the palm heart, callus formation was induced in the explants, following the protocol initially developed by Luis (2013), with modifications. The leaf explants were inoculated in a basic medium composed of salts of the Y3 culture medium (Eeuwens, 1976) and vitamins of the MS medium (Murashige and Skoog, 1962), supplemented with $30 \mathrm{~g} \mathrm{~L}^{-1}$ sucrose, $100 \mathrm{mg} \mathrm{L}^{-1}$ myo-inositol, and $2.5 \mathrm{~g} \mathrm{~L}^{-1}$ activated charcoal. The auxin 4-Amino-3,5,6-Trichloropicolinic Acid (Picloram) was added at a concentration of $450 \mu \mathrm{M}$. During the multiplication phase, the calli were separated from the explants and inoculated in a medium with the same composition as the previous phase. The medium used throughout the experiment was solidified with $2.5 \mathrm{~g} \mathrm{~L}^{-1}$ Phytagel (Sigma, St. Louis, MO) and $\mathrm{pH}$ was adjusted to $5.8 \pm 0.1$. Sterilization was performed by autoclaving at $121{ }^{\circ} \mathrm{C}$ and $1 \mathrm{~atm}$ pressure for $20 \mathrm{~min}$.

\subsection{Histological and histochemical analysis}

For the histological and histochemical analysis, samples of the material were taken in vitro at different stages of development. In vitro plant material samples were characterized by immature leaves with or without callus, collected at $0,3,15,30,60,90$ and 120 days after induction of somatic embryogenesis. Additionally, samples of the different types of calli and somatic embryos obtained during the multiplication phase were also collected.

The samples were fixed in FAA 70 (37\% Formaldehyde, Glacial Acetic Acid and 70\% Ethyl Alcohol, 1:1:18 v/v) for a period of $24 \mathrm{~h}$ under vacuum for the first hour. After fixation, the samples were dehydrated in an increasing ethanolic series (70-100\%) for $1 \mathrm{~h}$ each and infiltrated in historesin (Leica, Heidelberg, Germany), according to the manufacturer's specifications. Then, sections $(5-7 \mu \mathrm{m})$ were obtained by a manual rotary microtome (Leica ${ }^{\circledR}$, RM212RT), stretched and adhered to the microscopic slides on a plate heated to $40{ }^{\circ} \mathrm{C}$. The sections were stained with Toluidine Blue (O’Brien et al., 1964) and subjected to the Lugol test (Johansen, 1940) for starch detection according to methodology described by Ventrella et al. (2013). The results were recorded under a microscope (Leica ${ }^{\circledR}$ DM750) coupled to a computer with image capture software (LAS EZ 2.0).

\section{Results \& discussion}

Fig. 1 shows the anatomical characteristics of young and achlorophyllous leaves used as sources of explants in the induction of somatic embryogenesis of $A$. aculeata (Fig. 1A), as well as explants after 30 (Fig. 1B) and 60 days (Fig. 1C) of inoculation, with the onset of callus formation. The cross sections showed that the leaf explants have uniseriate epidermis, with cells of homogeneous size and juxtaposed. The stomata are leveled with the other epidermal cells and occur on the abaxial face, characterizing the leaf as hypostomatic (Fig. 1A). The mesophyll consists of the hypodermis on both sides, adjacent to the epidermis, and the homogeneous parenchyma, composed of polyhedral cells arranged compactly and interspersed by vascular bundles (Fig. 1A). The larger bundles are of the closed collateral type, surrounded by a sclerenchymatous outer sheath and a parenchymatous inner sheath, whereas the smaller bundles are in the process of differentiation, exhibiting only a parenchymatous sheath (Fig. 1A). After 30 days of cultivation of the leaf explants in the induction medium, development of hypertrophied cells in the parenchyma and on the abaxial face of the epidermis of the leaf explant was observed (Fig. 1B). At this phase, no signs of cell division and callus formation were observed.

At 60 days of cultivation, the presence of cells with meristematic characteristics, characterized by an isodiametric shape, presence of bulky nuclei, visible nucleoli, and dense cytoplasm with a high 


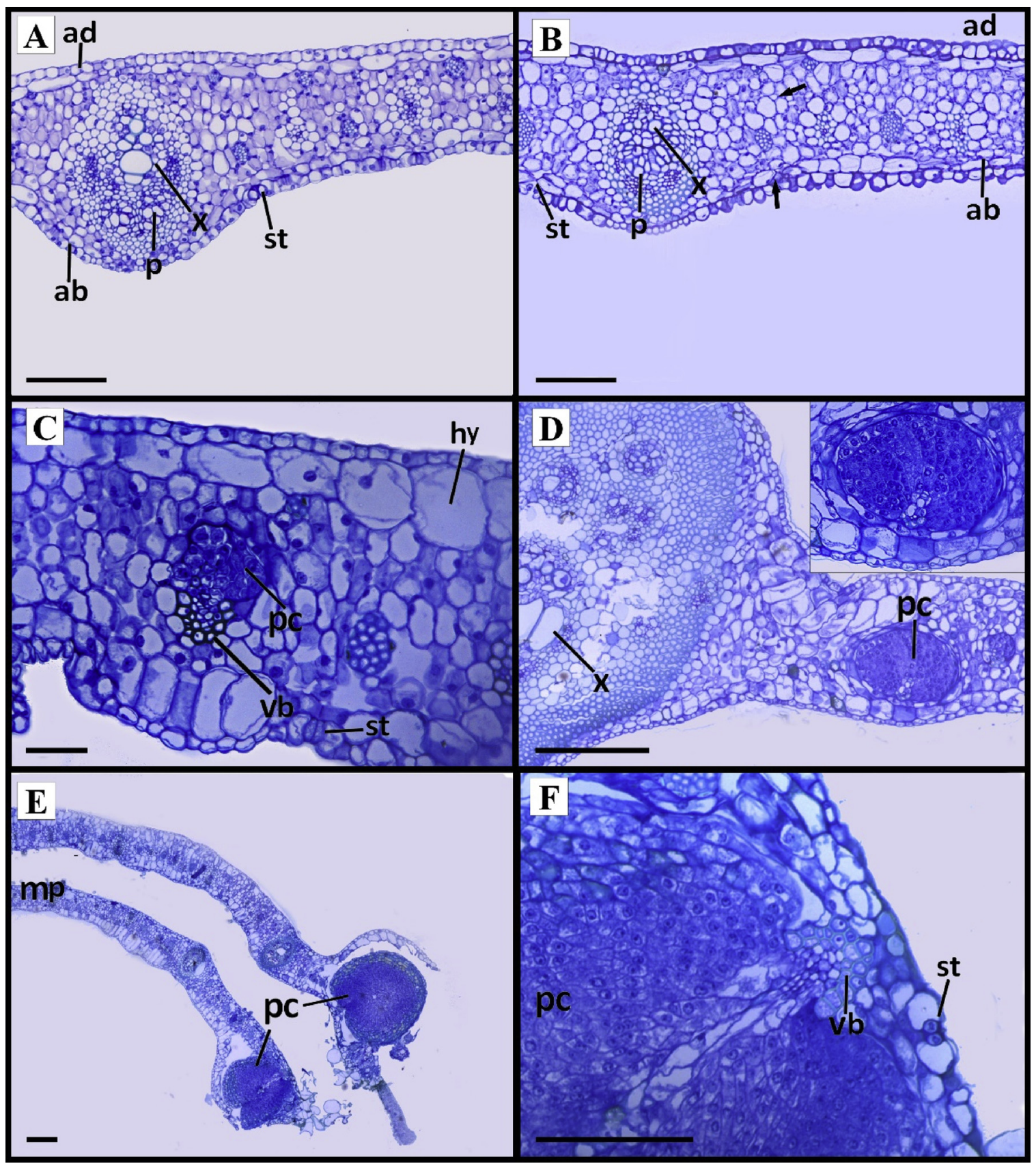

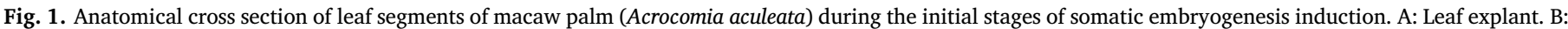

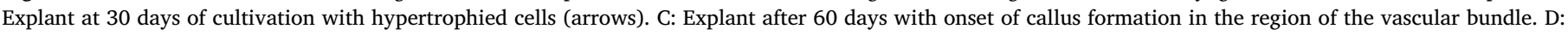

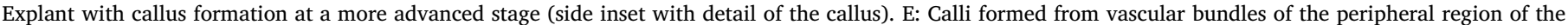

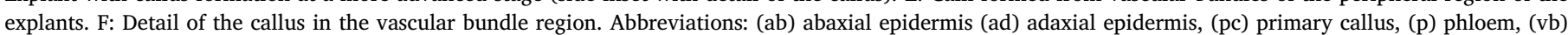
vascular bundle, (st) stomata, (hy) hypodermis, (mp) mesophyll, (x) xylem. Scales: A, B, D, E, F: $0.1 \mathrm{~mm}$ and C: $0.02 \mathrm{~mm}$.

nucleus:cytoplasm ratio were observed (Fig. 1C). These cells were probably derived from mitotic divisions from procambial or provascular cells (stem cells) located in the vicinity of vascular tissues and/or from the dedifferentiation of parenchymatous cells (perivascular and vascular system), which requires earlier ontogenic investigation for definitive affirmation. Repeated mitotic divisions, and in different directions, formed clusters of larger isolated cells, which subsequently gave rise to the primary calli. These cell clusters were associated with smaller vascular bundles, particularly those located in the regions near the edge of the leaf explant (Fig. 1D-F). It should be noted that the calli were isolated from the mesophyll cells from the beginning of their formation until their later development and detachment from the explant
(Fig. 1D).

The development of calli from cells close to vascular tissues has also been reported by other authors in species of the Arecaceae family, such as Calamus merrillii and C. subinermis (Goh et al., 2001), E. guineensis (Schwendiman et al., 1988; Gomes et al., 2017), Cocos nucifera (Buffard-Morel et al., 1992; Fernando et al., 2003), P. dactylifera (Sané et al., 2006) and B. gasipaes (Steinmacher et al., 2011). This close relationship between vascular/perivascular cells and the formation of calli may be related - as mentioned above - to two hypotheses: $i$ ) division of procambial cells (vascular stem cells), responsible for the formation of vascular bundles of different organs during plant growth (Fukuda, 2004) and ii) cellular dedifferentiation, as reported by Yusoff 


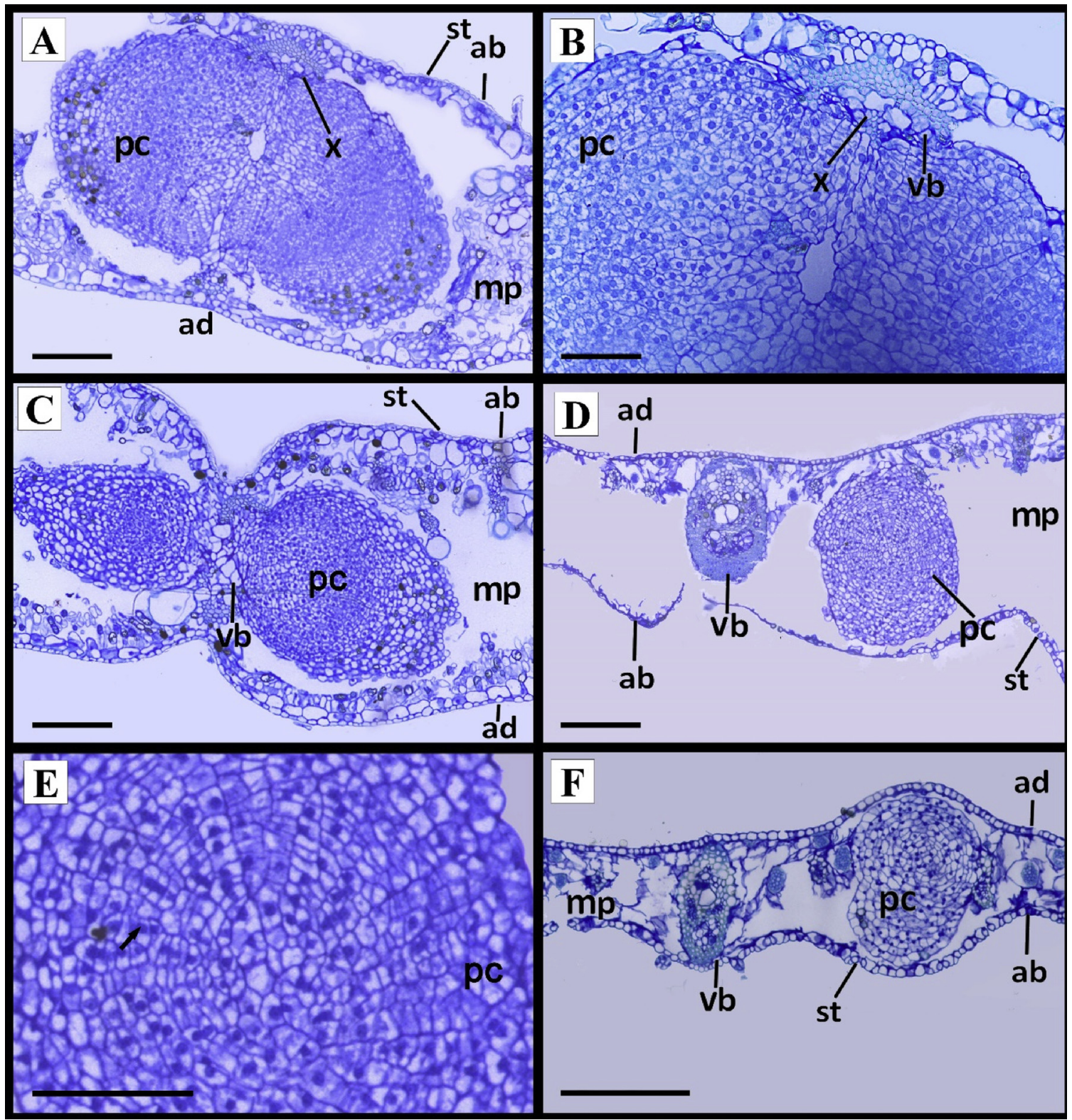

Fig. 2. Anatomical cross section of macaw palm leaf segments (Acrocomia aculeata) during the final stages of somatic embryogenesis induction. A, C: Callus formed in the vascular bundle region after 90 days of cultivation. B: Detail of the remnant of the vascular bundle and of the callus formed. D: Callus formed in the vascular bundle region at 120 days of cultivation. E: Callus formed at 120 days of cultivation with meristematic cells undergoing cell division (arrow). F: Leaf after 120 days of cultivation with primary callus and absence of the mesophyll region. Abbreviations: (ab) abaxial epidermis, (ad) adaxial epidermis, (pc) primary callus, (st) stomata, (p) phloem, (vb) vascular bundle, (mp) mesophyll, (x) xylem. Scale: A, C, D, F: $0.1 \mathrm{~mm}$; B: $0.05 \mathrm{~mm}$ and E: $0.02 \mathrm{~mm}$.

et al. (2012). Whatever the hypothesis, the effectiveness of the auxin Picloram used in this experiment to induce the cellular divisions responsible for callus formation is widely known.

According to research conducted by Gomes et al. (2017), there is evidence to confirm the origin of the calli from procambium cells due to initial cell proliferation close to the vascular bundle and absence of signs of dedifferentiation in parenchymatous cells in the early ontogenic stages of the calli. Moreover, Rose et al. (2006) suggest that procambium cells, which normally differentiate into vascular tissues, are reprogrammed after being stimulated by the auxin present in the culture medium, promoting cell proliferation and callus formation. More recently, Rose (2016) reported the participation of these cells in the formation of somatic embryos. Surely some of these procambial cells become totipotent in the absence of normal "vascular" signals following exposure to the exogenous auxin (Kwaaitaal and Vries, 2007). Differently, Sané et al. (2006) and Gueye et al. (2009) described the occurrence of cell divisions in the area of the perivascular parenchyma in leaf explants of date palm in the first weeks of in-vitro cultivation. Gueye et al. (2009) divided the reactions in this region into two events: the first event involves cells of the parenchyma perpendicular to the vascular axis that acquire typically meristematic characteristics, and the second event is characterized by the alteration of cells of the adjacent perivascular sheath, which become callogenic and undergo cell division, leading to callus formation.

At 90 days, the calli were visually larger in size than those observed at 60 days of cultivation. Anatomically, it was found that this increase in size was a consequence of the cell proliferation inside the callus, which resulted in the removal of the epidermal faces, causing mesophilic disorganization and cell loss (Fig. 2A-C).

At 120 days, the epidermis of the leaf explant ruptured and the calli were exposed on the leaf surface (Fig. 2D-F). The exposed calli had an elongated shape, compact consistency, yellowish coloration, and 


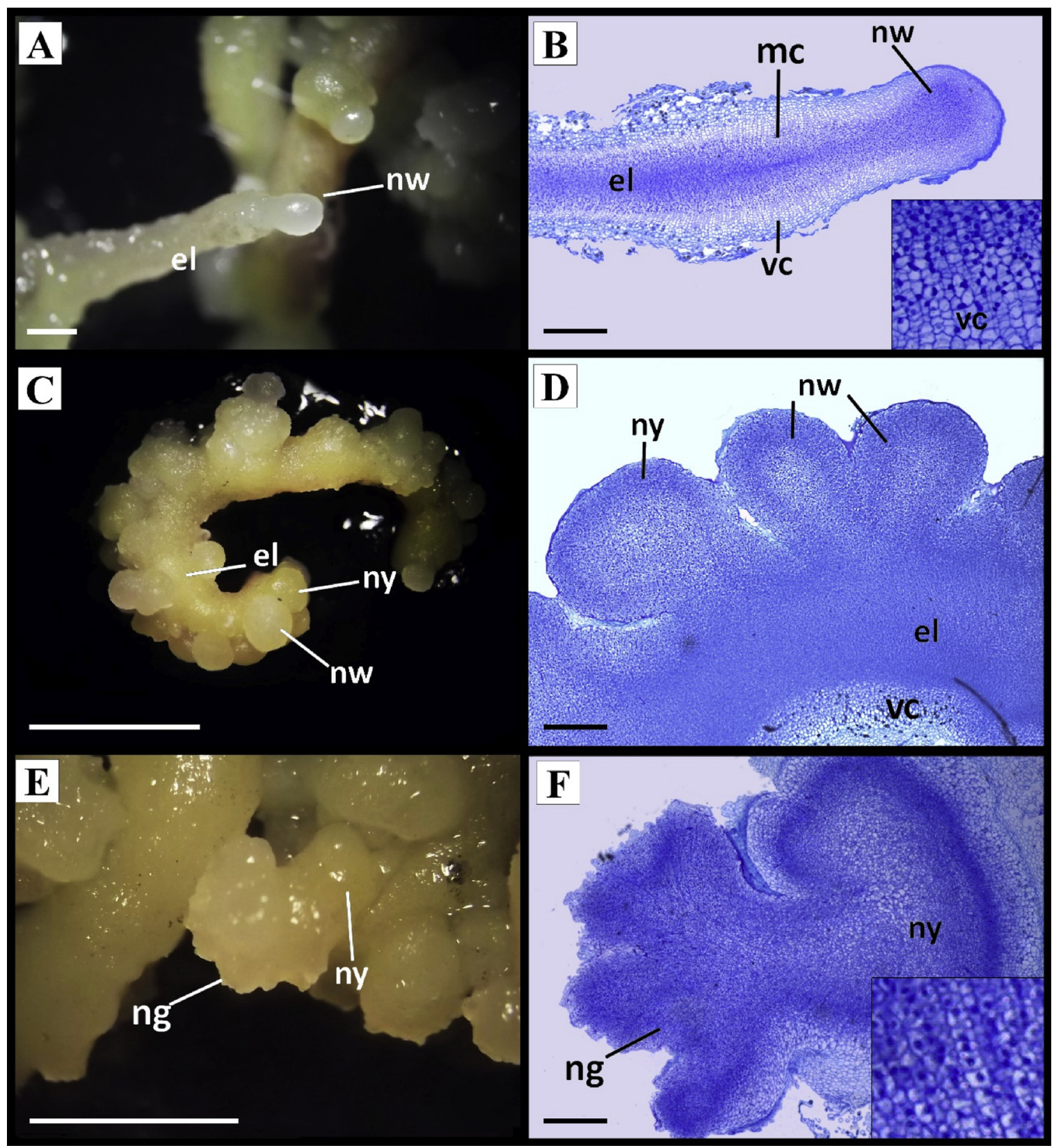

Fig. 3. Anatomy of lineages of calli obtained from macaw palm leaf tissues (Acrocomia aculeata). A: Elongated callus with white nodular callus at its end. B: Longitudinal section of the elongated callus with meristematic cells in the central region; the square details the vacuolated peripheral cells. C: Yellow elongated callus with white and yellow nodular calli on its surface. D: Section of the elongated callus with nodular calli (white and yellow) on its surface composed of meristematic cells. E: Granular callus starting from elongated callus. F: Section of granular callus formed by meristematic cells; the square details the apparent nuclei of meristematic cells. Abbreviations: (el) elongated callus, (ng) nodular granular, (nw) nodular white, (ny) nodular yellow, (vc) vacuolated cells, (mc) meristematic cells. Scales: A, C, E: $0.5 \mathrm{~cm}$; B, F: $0.2 \mathrm{~mm}$ and D: $0.1 \mathrm{~mm}$ (For interpretation of the references to colour in this figure legend, the reader is referred to the web version of this article).

consisted of parenchymatous cells in the peripheral region and meristematic cells in the inner region, forming a bundle. A similar anatomical pattern has been reported in other studies on palm trees (BuffardMorel et al., 1992; Gueye et al., 2009; Gomes et al., 2017).

After the explants remained in the induction medium for 180 days, the calli were isolated from the leaf and transferred to a new medium for maintenance and proliferation. In this stage, the elongated calli obtained in the induction phase proliferated, and new lineages of calli were formed from the elongated calli. The new lineages of calli exhibited a nodular yellow, nodular whitish or granular appearance. In this study, the nodular yellowish calli were classified as embryogenic.

In fact, the lineage of yellow nodular calli exhibits anatomical characteristics similar to that of the white nodules, being predominantly composed of meristematic cells (Fig. 3A-D). However, the granular calli lineages exhibit an irregular surface and were formed predominantly by meristematic cells with events of cell division (Fig. 3E-F). Pádua et al. (2013) also classified lineages of African oil palm calli regarding color and shape: translucent-elongated, translucent-aqueous, beige-globular, and white-globular. These authors considered the lineages of beige-globular and white-globular calli as having the greatest embryogenic potential, based on the anatomical aspects. Similarly, Luis and Scherwinski-Pereira (2014) working with zygotic embryos, observed that the calli of nodular strains in macaw palm showed greater embryogenic potential, and differentiation of somatic 


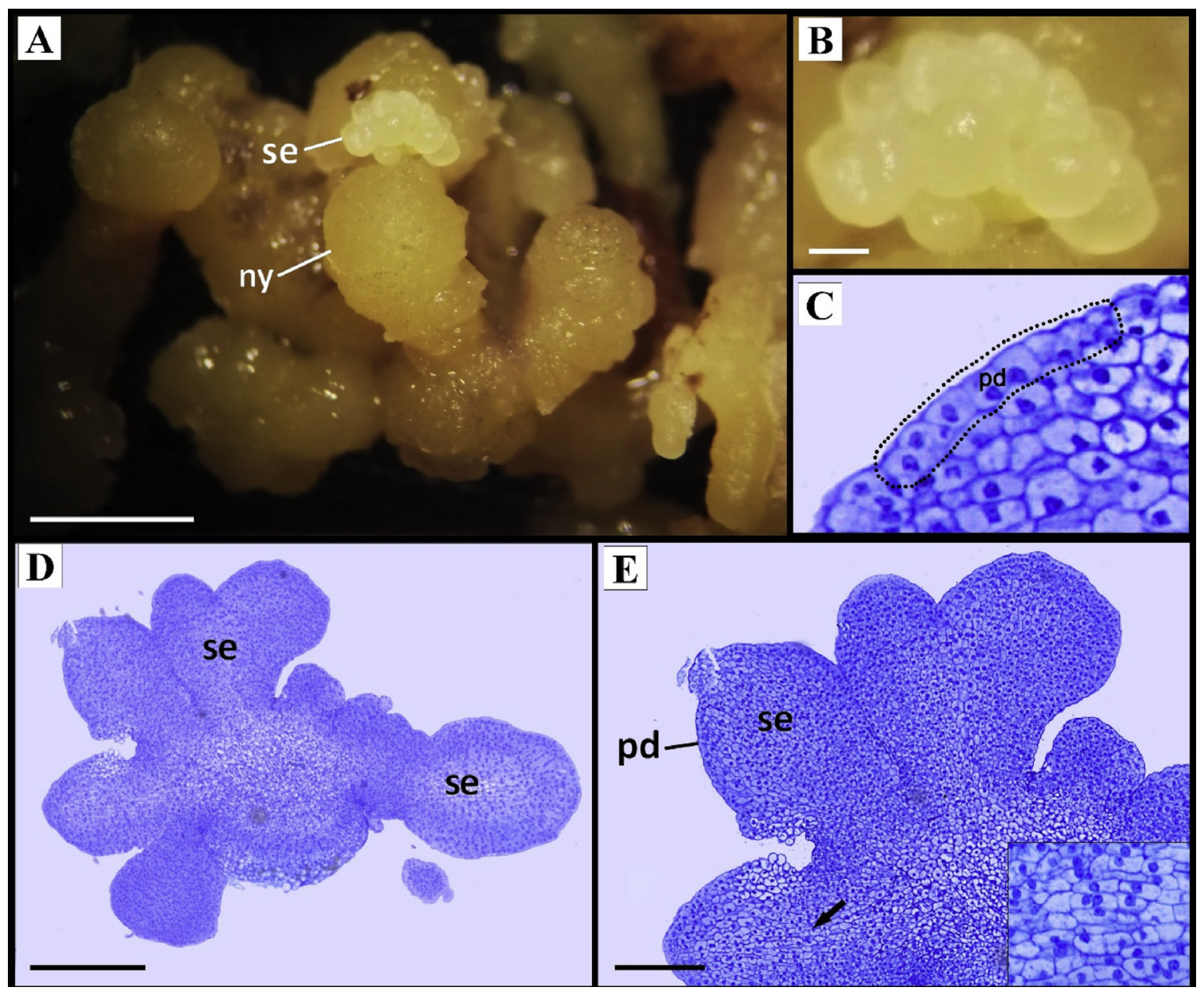

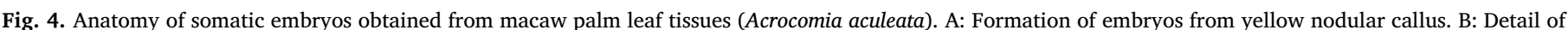

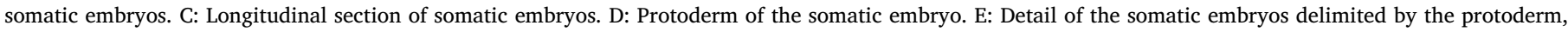

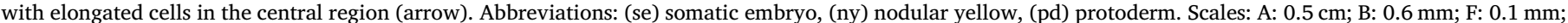
D: $0.25 \mathrm{~cm}$ and E: $0.2 \mathrm{~mm}$ (For interpretation of the references to colour in this figure legend, the reader is referred to the web version of this article).

embryos was observed from these calli.

In proliferation medium, there was the formation of somatic embryos, seen in a globular stage with whitish coloration (Fig. 4A-B). The somatic embryos were shown to consist of meristematic cells of different formats and sizes. The outermost layer of cells of the embryos is the protoderm, precursor meristem of the epidermis characterized by a layer of juxtaposed cells and prominent nucleus (Fig. 4C). Several authors consider the presence of protoderm as an indicator of somatic embryo formation (Yeung, 1995; Jalil et al., 2008; Moura et al., 2010; Aslam et al., 2011). Adjacent to the protoderm, the cells are polyhedral and larger, whereas those that occupy the central region of the embryo exhibit an elongated shape, with their largest axis parallel to the largest axis of the somatic embryo, characterizing procambium cells, the precursor meristem of vascular tissues (Fig. 4 D-E). Aside from the aforementioned characteristics, somatic embryos sectioned and analyzed anatomically showed no vascular connection with the callus of origin, which ratifies the somatic embryogenesis pathway. Additionally, due to the absence of proembryos and suspensors in the anatomical sections analyzed, as well as the apparent fusion of the somatic embryos obtained, a multicellular origin thereof is suggested (Fig. 4D-E).

Histochemical analysis showed that the accumulation of starch during the process of somatic embryogenesis was concentrated near the centers in intense cell division (Fig. 5), probably subsidizing them in terms of energy. At three days of cultivation, starch was present in the vascular bundle sheath region (Fig. 5A). However, at 15 days and 30 days, no accumulation was observed in this region (Fig. 5B-C). At 60 days of induction, there was starch accumulation in the region close to formation of calli (Fig. 5D-F). The storage of starch grains during somatic embryogenesis in palms is commonly related to the differentiation of embryogenic cells by several authors, as observed in $C$. nucifera (Verdeil et al., 2001) and E. guineensis (Schwendiman et al., 1988; Kanchanapoom and Domyoas, 1999). However, other authors do not consider this relationship as systematic (Schwendiman et al., 1988; Steinmacher et al., 2011), which requires more detailed investigations.

The presence of starch in the lineages of calli was not observed (Fig. 6A-C). This may be related to the fact that these calli, in general, are composed of meristematic cells undergoing intense division or as a consequence of the phase in which the callus was encountered. Unlike the foregoing, Pádua et al. (2013) when analyzing the accumulation of starch in lineages of calli, observed that beige nodular calli exhibited starch storage.

Globular somatic embryos also exhibited no starch accumulation (Fig. 6D), probably due to the intense metabolic activity that preceded the more advanced stages of somatic embryo development. In contrast, Moura et al. (2010) observed the presence of starch in the cells of the somatic embryo, although not as abundantly and with non-uniform distribution. The somatic embryo may follow the same zygote developmental sequence and exhibit embryonic cells undergoing active division, with reduced size, dense cytoplasmic content, large nuclei with prominent nucleoli, small vacuoles, and the presence of starch grains (Guerra et al., 1999) However, the amount of starch may also change depending on the growth phase of the embryo, since cell division and 


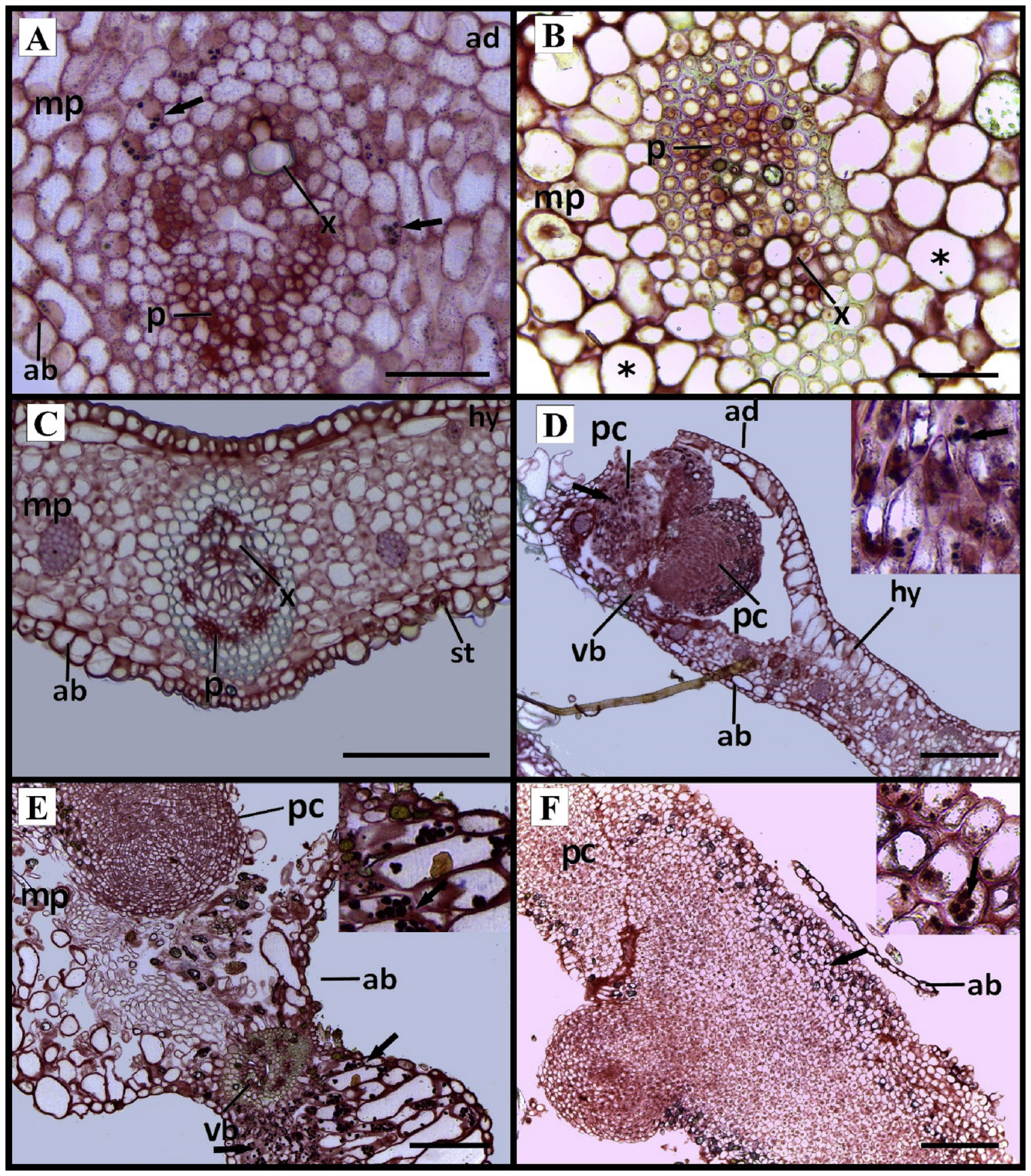

Fig. 5. Cross section of leaf segments of macaw palm (Acrocomia aculeata) submitted to the Lugol test during induction of somatic embryogenesis. A: Leaf explant at three days of cultivation; note the starch in the region of the vascular bundle sheath (arrow). B: Explant at 15 days of cultivation with hypertrophied cells (*). C: Explant after 30 days of induction with absence of starch. D: Explant at 60 days of cultivation with callus formation and presence of starch at its extremity (arrows); note dark starch grains in the side detail. E: Callus with starch accumulation (arrow) after 90 days of cultivation; note dark starch grains in the side detail. F: Callus at 120 days with starch accumulation (arrows) and remnant of the leaf epidermis; note dark starch grains in the side detail. Abbreviations: (ab) abaxial epidermis, (ad) adaxial epidermis, (pc) primary callus, (st) stomata, (p) phloem, (vb) vascular bundle, (hy) hypodermis, (mp) mesophyll, (x) xylem. Scales: A, B: 0.05 mm and C, D, F: $0.2 \mathrm{~mm}$.

differentiation demand energy (Gomes et al., 2014).

\section{Conclusion}

In conclusion, in an unprecedented way, this work describes the ontogenesis of calli and somatic embryos of macaw palm (Acrocomia aculeata) from leaf tissues of adult plants. Morpho-anatomic markers of embryogenic calli are described in this study (yellow nodular calli with a predominance of meristematic cells), as well as identification of the leaf areas involved in the embryogenic process in this species (smaller vascular bundles). Such information may support the elucidation of the mechanisms involved in somatic embryogenesis in palm trees derived from leaf tissues of adult plants.

\section{Acknowledgements}

The authors thank the Conselho Nacional de Desenvolvimento Científico e Tecnológico (CNPq Grant 426637/2016-0), Financiadora de Estudos e Projetos (Finep Grant 01.08.0597.01), and Coordenação de Aperfeiçoamento de Pessoal de Nível Superior (Capes/Embrapa 001- 


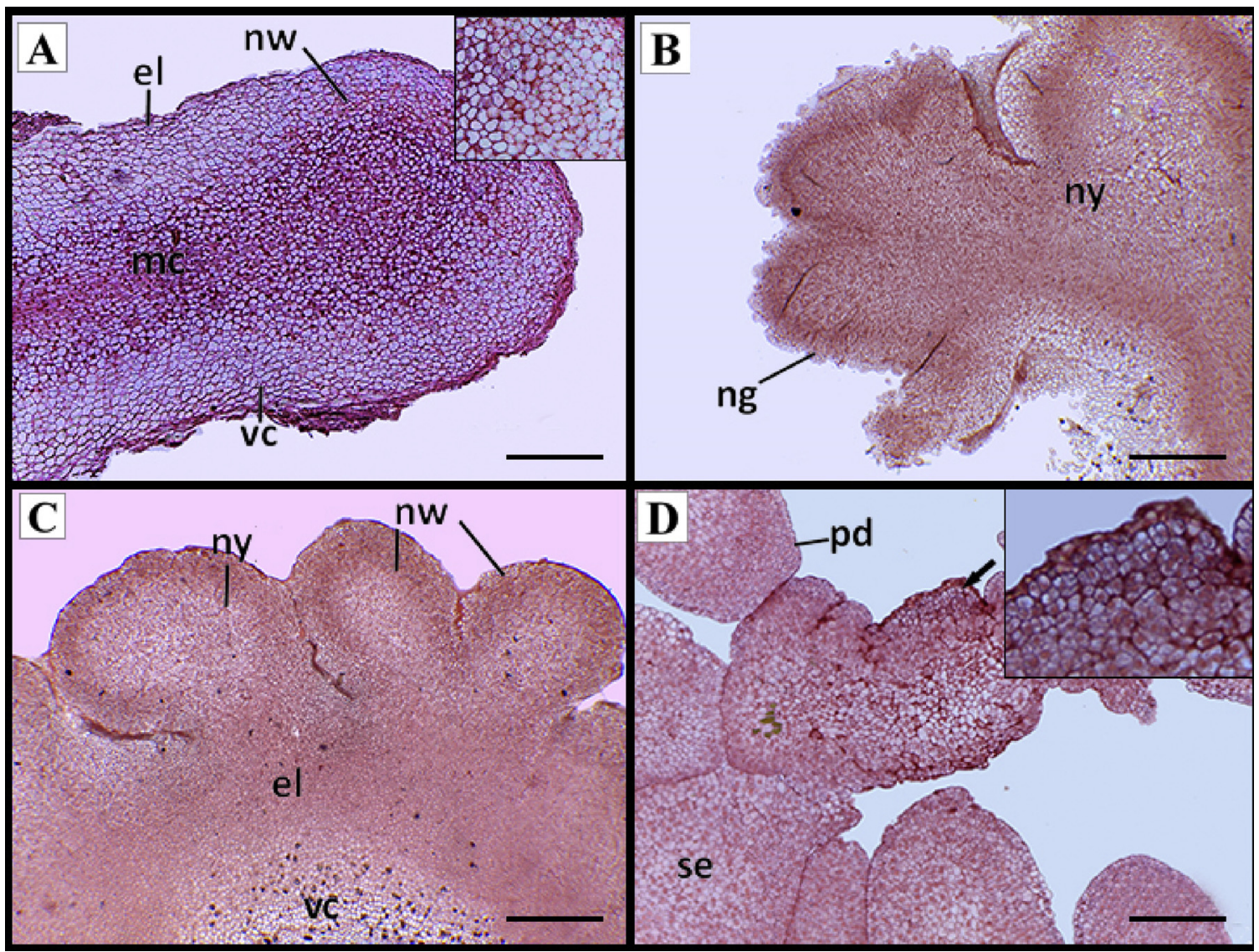

Fig. 6. Histochemical analysis of different lineages of calli and somatic embryos obtained from macaw palm leaf tissues (Acrocomia aculeata) (stained with Lugol). A: Elongated callus showing white nodular callus at its end; the square details the peripheral region of the callus. B: Granular callus formed from the yellow nodular callus. C: Yellow elongated callus with white and yellow nodular callus on its surface, and no starch. D: Somatic embryos; the square details the region indicated by the arrow. Abbreviations: (el) elongated callus, (mc) meristematic cells, (vc) vacuolated cells, (ny) nodular yellow, (nw) nodular white, (ng) nodular granular, (se) somatic embryo, (pd) protoderm. Scales: A, D: $0.2 \mathrm{~mm}$ and B, C: $0.5 \mathrm{~mm}$. (For interpretation of the references to colour in this figure legend, the reader is referred to the web version of this article).

2011/Grant 39) for financial support and fellowships.

\section{References}

Ahée, J., Arthuis, P., Cas, G., Duval, Y., Guénin, G., Hanower, J., Hanower, P., Lievoux, D., Lioret, C., Malaurie, B., Pannetier, C., Raillot, D., Varechon, C., Zuckerman, L., 1981. La multiplication végétative ín vítro du palmier à huile par embryogenèse somatique. Olagineux 36, 113-118.

Amaral, F.P., Broetto, F., Batistella, C.B., Jorge, S.M.A., 2011. Extração e caracterização qualitativa do óleo da polpa e amêndoas de frutos de macaúba [Acrocomia aculeata (jacq) lodd. Ex mart] coletada na região de Botucatu, SP Botucatu. Rev. Energy Agric. $26,12-20$.

Aslam, J., Khan, S.A., Cheruth, A.J., Mujib, A., Sharma, M.P., Srivastava, P.S., 2011. Somatic embryogenesis, scanning electron microscopy, histology and biochemical analysis at different developing stages of embryogenesis in six date palm (Phoenix dactylifera L.) cultivars. Saudi J. Biol. Sci. 18, 369-380.

Balzon, T.A., Luis, Z.G., Scherwinski-Pereira, J.E., 2013. New approaches to improve the efficiency of somatic embryogenesis in oil palm (Elaeis guineensis Jacq.) from mature zygotic embryos. In Vitro Cell. Dev. Biol. - Plant 49, 41-50.

Buffard-Morel, J., Verdeil, J.L., Pannetier, C., 1992. Embryogenese somatique du cocotier (Cocos nucifera L) a partir d'explants foliaires: études histologiques. Can. J. Botany 70, $735-741$.

César, A.S., Almeida, F.A., Souza, R.P., Silva, G.C., Atabani, A.E., 2015. The prospects of using Acrocomia aculeata (macaúba) a non-edible biodiesel feedstock in Brazil. Renew. Sust. Energ. Rev. 49, 1213-1220.

Ciconini, G., Favaro, S.P., Roscoe, R., Miranda, C.H.B., Tapeti, C.F., Miyahira, M.A.M., Bearari, L., Galvani, F., Borsato, A.V., Colnago, L.A., Naka, M.H., 2013. Biometry and oil contents of Acrocomia aculeata fruits from the cerrados and pantanal biomes in Mato Grosso do Sul, Brazil. Ind. Crops Prod. 45, 208-214.

Dario, M.F., Oliveira, F.F., Marins, D.S.S., Baby, A.R., Velasco, M.V.R., Löbenberg, R., Bou-Chacra, N.A., 2018. Synergistic photoprotective activity of nanocarrier containing oil of Acrocomia aculeata (Jacq.) Lodd. Ex. Martius-Arecaceae. Ind. Crops Prod. 112, 305-312.

Dias, L.A.S., 2011. Biofuel plant species and the contribution of genetic improvement.
Crop Breed Appl. Biotechnol. S1, 16-26.

Eeuwens, C.J., 1976. Mineral requirements for growth and callus initiation of tissue explants excised from mature coconut palms (Cocos nucifera) and cultured in vitro. Physiol. Plant. 36, 23-28.

Fernando, S.C., Verdeil, J.L., Hocher, V., Weerakoon, L.K., Hirimburegama, K., 2003. Histological analysis of plant regeneration from plumule explants of Cocos nucifera. Plant Cell Tissue Organ Cult. 72, 281-284.

Fki, L., Masmoudi, R., Drira, N., Rival, A., 2003. An optimised protocol for plant regeneration from embryogenic suspension cultures of date palm, Phoenix dactylifera L., cv. Deglet Nour. Plant Cell Rep. 21, 517-524.

Fukuda, H., 2004. Signals that control plant vascular cell differentiation. Nature Rev. 5, 379-391.

Goh, D.K.S., Bon, M.C., Aliotti, F., Escoute, J., Ferrière, N., Monteuuis, O., 2001. In vitro somatic embryogenesis in two major rattan species:Calamus merrillii and Calamus subinermis. In Vitro Cell. Dev-Pl. 37, 375-381.

Gomes, H.T., Bartos, P.M.C., Silva, C.O., Amaral, L.I.V., Scherwinski-Pereira, J.E., 2014 Comparative biochemical profiling during the stages of acquisition and development of somatic embryogenesis in African oil palm (Elaeis guineensis Jacq.). Q. 74, 199-2008.

Gomes, H.T., Bartos, P.M.C., Scherwinski-Pereira, J.E., 2017. Dynamics of morphological and anatomical changes in leaf tissues of an interspecific hybrid of oil palm during acquisition and development of somatic embryogenesis. Plant Cell Tiss. Organ Cult. 131, 269-282.

Granja, M.M.C., Motoike, S.Y., Andrade, A.P.S., Correa, T.R., Picoli, E.A.T., Kuki, K.N., 2018. Explant origin and culture media factors drive the somatic embryogenesis response in Acrocomia aculeata(Jacq.) Lodd. ex Mart., an emerging oil crop in the tropics. Ind. Crops Prod. 117, 1-12.

Guerra, M.P., Torres, A.C., Teixeira, J.B., 1999. Embriogênese somática e sementes sintéticas. In: Torres, A.C., Caldas, L.S., Buso, J.A. (Eds.), Culturas De Tecidos E Transformação Genética De Plantas. Embrapa-CBAB, Brasília.

Gueye, B., Morcillo, F., Collin, M., Gargani, D., Overvoorde, P., Aberlenc-Bertossi, F., Tranbarger Sane, D., Tregear, J.W., Borgel, A., Verdeil, F., 2009. Acquisition of callogenic capacity in date palm leaf tissues in response to 2,4-D treatment. Plant Cell Tissue Organ Cult. 99, 35-45.

Henderson, A., Galeano, G., Bernal, R., 1995. Field Guide to the Palms of the Americas. 
Princepton University, New Jersey.

Heringer, A.S., Steinmacher, D.A., Fraga, H.P., Vieira, L.N., Montagna, T., Quinga, L.A., Guerra, M.P., 2014. Improved high-efficiency protocol for somatic embryogenesis in Peach Palm (Bactris gasipaes Kunth) using RITA $^{\circledR}$ temporary immersion system. Sci. Hortic. 179, 284-292.

Jalil, M., Chee, W.W., Othman, R.Y., Khalid, N., 2008. Morphohistological examination on somatic embryogenesis of Musa acuminata cv. Mas (AA). Sci. Hortic. 117, 335-340.

Johansen, D.A., 1940. Plant Microtechnique. McGraw-Hill, New York.

Kanchanapoom, K., Domyoas, P., 1999. The origin and development of embryoids in oil palm (Elaeis guineensisJacq) embryo culture. Sci. Asia 25, 195-202.

Kwaaitaal, M.A.C.J., Vries, S.C., 2007. The SERK1 gene expressed in procambium and immature vascular cells. J. Exp. Bot. 58, 2887-2896.

Lleras, E., Coradin, L., 1985. Palmeras nativas como oleaginosas: situación actual y perspectivas para América Latina. In: Forero, L.E. (Ed.), Informe del seminário taller sobre oleaginosas promisorias. Asociación Interciencia/Asociación Colombiana para el Avance de la Ciencia, Bogotá, p. 92-143.

Lorenzi, G.M.A., 2006. Acrocomia aculeata (Jacq.) Lodd Ex Mart - Arecaceae: bases Para O Extrativismo Sustentável. Tese, Universidade Federal Do Paraná.

Lorenzi, G.M.A.C., Negrelle, R.R.B., 2006. Acrocomia aculeata(Jacq.) Lodd. ex Mart.: aspectos ecológicos, usos e potencialidades. Visão Acadêmica 7, 1-12.

Lorenzi, H., Noblick, L., Kahn, F., Ferreira, E., 2010. Flora Brasileira: Arecaceae (Palmae). Instituto Plantarium, Nova Odessa, Brasil.Flora Brasileira: Arecaceae (Palmae). Instituto Plantarium, Nova Odessa, Brasil.

Luis, Z.G., 2013. Estratégias Para a Embriogênese Somática E Conservação Ex Situ De Germoplasma De Macaúba [Acrocomia aculeata (Jacq.) Lodd. Ex Mart.]. Tese, Universidade De Brasília.

Luis, Z.G., Scherwinski-Pereira, J.E., 2014. An improved protocol for somatic embryogenesis and plant regeneration in macaw palm (Acrocomia aculeata) from mature zygotic embryos. Plant Cell Tiss. Organ Cult. 118, 485-496.

Matsimbe, S.F.S., 2012. Utilização De Características Ópticas Para Estimar O Teor De Óleo E Volume Do Mesocarpo Nos Frutos De Macaúba. Dissertação, Universidade Federal De Viçosa.

Montoya, S.G., Motoike, S.Y., Kuki, K.N., Couto, A.D., 2016. Fruit development, growth, and stored reserves in macauba palm (Acrocomia aculeata), an alternative bioenergy crop. Planta 244, 927-938.

Moura, E.F., Motoike, S.Y., Ventrella, M.C., Sá Júnior, A.Q., Ferreira, M.C., Carvalho, M., 2009. Somatic embryogenesis in macaw palm (Acrocomia aculeata) from zygotic embryos. Sci. Hortic. 119, 447-454.

Moura, E.F., Ventrella, M.C., Motoike, S.Y., 2010. Anatomy, histochemistry and ultrastructure of seed and somatic embryo of Acrocomia aculeata (Arecaceae). Sci. Agric. 67, 399-407.

Murashige, T., Skoog, F., 1962. A revised medium for rapid growth and bioassays with tobacco tissue cultures. Physiologia 15, 473-497.

O'Brien, T.P., Feder, N., Mccully, M.E., 1964. Polychromatic staining of plant cell walls by toluidine blue. Protoplasma 59, 368-373.

Othmani, A., Bayoudh, C., Drira, N., Marrakchi, M., Trifi, M., 2009. Somatic embryogenesis and plant regeneration in date palm Phoenix dactylifera L., cv. Boufeggous is significantly improved by fine chopping and partial desiccation of embryogenic callus. Plant Cell Tiss. Organ Cult. 97, 71-79.

Pádua, M.S., Paiva, L.V., Labory, C.R.G., Alves, E., Stein, V.C., 2013. Induction and characterization of oil palm (Elaeis guineensis Jacq.) pro-embryogenic masses. An. Acad. Bras. Cienc. 85, 1545-1556.

Rose, R.J., 2016. Genetic reprogramming of plant cells in vitro via dedifferentiation or pre-existing stem cells. In: Rose, R.J. (Ed.), Molecular Cell Biology of the Growth and Differentiation of Plant Cells. CRC Press, Boca Rato, pp. 320-339.

Rose, R.J., Wang, X.D., Nolan, K.E., Rolfe, B.G., 2006. Root meristems in Medicago truncatula tissue culture arise from vascular derived procambial-like cells in a process regulated by ethylene. J. Exp. Bot. 57, 2227-2235.

Sané, D., Aberlenc-Bertossi, F., Gassama-Dia, Y.K., Sagna, M., Trouslot, M.F., Duval, Y., Borgel, A., 2006. Histocytological analysis of callogenesis and somatic embryogenesis from cell suspensions of date palm (Phoenix dactylifera). Ann. Bot. 98, 301-308.

Scariot, A.O., Lleras, E., Hay, J.D., 1991. Reproductive biology of the palm Acrocomia aculeata in Central Brazil. Biotropica 23, 12-22.

Scherwinski-Pereira, J.E., Guedes, R.S., Fermino, P.C.P., Silva, T.L., Costa, F.H.S., 2010. Somatic embryogenesis and plant regeneration in oil palm using the thin cell layer technique. In Vitro Cell. Dev.-Pl. 46, 378-385.

Scherwinski-Pereira, J.E., Guedes, R.S., Silva, R.A., Fermino Jr., P.C.P., Luis, Z.G., Freitas, E.O., 2012. Somatic embryogenesis and plant regeneration in açaí palm (Euterpe oleracea). Plant Cell Tiss. Org. Cult. 109, 501-508.

Schex, R., Lieb, V.M., Jiménez, V.M., Esquivel, P., Schweiggert, R.M., Carle, R., Steingass, C.B., 2018. HPLC-DAD-APCI/ESI-MSn analysis of carotenoids and $\alpha$ - tocopherol in Costa Rican Acrocomia aculeata fruits of varying maturity stages. Food Res. Int. 105, 645-653.

Schwendiman, J., Pannetier, C., Michaux-Ferriere, N., 1988. Histology of somatic embryogenesis from leaf explants of the oil palm Elaeis guineensis. Ann. Bot. 62, 43-52.

Silva, P.V.B., Ramiro, M.M., Iriguchi, E.K.K., Corrêa, W.A., Lowe, J., Cardoso, C.A.L., Arena, A.C., Kassuya, A.L.C., Muzzi, R.M., 2018. Antidiabetic, cytotoxic and antioxidant activities of oil extracted from Acrocomia aculeata pulp. Nat. Prod. Res. 1-4.

Silva, R.C., Luis, Z.L., Scherwinski-Pereira, J.E., 2012. Differential responses to somatic embryogenesis of different genotypes of Brazilian oil palm (Elaeis guineensis Jacq.). Plant Cell Tissue Organ Cult. 111, 59-67.

Steinmacher, D.A., Cangahuala-Inocente, G.C., Clement, C.R., Guerra, M.P., 2007. Somatic embryogenesis from immature peach palm inflorescence explants: towards development of an efficient protocol. Plant Cell Tissue Organ Cult. 89, 15-22.

Steinmacher, D.A., Guerra, M.P., Saare-Surminski, K., Lieberei, R., 2011. A temporary immersion system improves in vitro regeneration of peach palm through secondary somatic embryogenesis. Ann. Bot. 108, 1463-1475.

Teixeira, J.B., Söndahl, M.R., Kirby, E.G., 1993. Somatic embryogenesis from immature zygotic embryos of oil palm. Plant Cell Tissue Organ Cult. 34, 227-233.

Teixeira, L.C., 2005. Potencialidades de oleaginosas para produção de biodiesel. Informe Agrop. 26, 18-27.

Ventrella, M.C., Almeida, A.L., Nery, L.A., Coelho, V.P.D.M., 2013. Métodos Histoquímicos Aplicados Às Sementes. Editora UFV, Viçosa.

Verdeil, Hocher, V., Huet, C., Grosdemange, F., Escoute, J., Ferriere, N., M, 2001. Ultrastructural changes in coconut calli associated with the acquisition of embryogenic competence. Ann. Bot. 88, 9-18.

Wandeck, F.A., Justo, P.G., 1988. A macaúba, fonte energética e insumo industrial: sua significação econômica no Brasil. Simpósio sobre o Cerrado, Savanas, 1988, Brasília, DF. Embrapa, CPAC, Planaltina, pp. 541-577.

Yeung, E.C., 1995. Structural and development patterns in somatic embryogenesis. In: Thorpe, T.A. (Ed.), In Vitro Embryogenesis in Plants. Kluwer Academic Publishers, Dordrecht, The Netherlands, pp. 205-248.

Yusoff, N.F.M., Alwee, S.S.R.S., Abdullah, M.O., Chai-Ling, H., Namasivayam, P., 2012. A time course anatomical analysis of callogenesis from young leaf explants of oil palm (Elaeis guineensis Jacq.). J. Oil Palm Res. 24, 1330-1341.

Zelt, T., 2018. In: Kaltschmitt, M., Neuling, U. (Eds.), "New" Oil Plants and Their Potential as Feedstock for Biokerosene Production. Springer, Berlin, pp. 277-301. 